\title{
Hydrological drought in the Bohemian Forest region
}

\author{
VÍT SKÁLA, BOHUMÍR JANSKÝ
}

Univerzita Karlova, Přírodovědecká fakulta, katedra fyzické geografie a geoekologie, Praha, Česko (Charles University, Faculty of Science, Department of Physical Geography and Geoecology, Prague, Czechia); e-mail: skalav@natur.cuni.cz, jansky@natur.cuni.cz

ABSTRACT Hydrological drought in the Bohemian Forest region - The aim of this study was to select and apply appropriate methods for evaluating hydrological drought in the mountainous Bohemian Forest region. The results from individual hydrological profiles were compared with each other, followed by a general comparison of catchment areas in the extramontane region. The threshold and Gumbel (1963) methods, and a calculation of scarcity volumes, were used. In this way, dry days and episodes were defined, seasonal charts were compiled, and trends were assessed using the Mann-Kendall and Hirsch-Slack trend tests. It was found that the seasonality of the hydrological droughts on the windward and leeward sides of the mountains differed significantly. The maximum number of dry days was found to occur in the windward profiles in autumn and in the leeward profiles in winter. The amount of winter drought decreases with decreasing altitude. Significant decreases in the occurrence of hydrological drought were found in all profiles for the observed period.

KEY WORDS hydrological drought - hydrological drought indices - seasonality - trends Bohemian Forest

SKÁLA, V., JANSKÝ, B. (2020): Hydrological drought in the Bohemian Forest region. Geografie, 125, 3, 271-290.

https://doi.org/10.37040/geografie2020125030271

Received March 2019, accepted February 2020.

C Česká geografická společnost, z. s., 2020 


\section{Introduction}

In recent years, drought has been thrust to the forefront of climatic research, becoming a prominent issue for debate and investigation in fields other than that of simply hydrology. The attention devoted to this topic has transcended that of flood studies, which dominated hydrological research in the early 21st century.

This study deals with the issue of hydrological drought in the lesser studied environment of a mountainous region - the Eastern European Bohemian Forest. Whilst this area is generally rich in precipitation, its study may provide answers to some of the questions that have arisen in the study of drought. The aim of this study was to describe the characteristics of the hydrological profiles of the Bohemian Forest and its closest surroundings, with a focus on the occurrence of hydrological drought. The work was grouped into three objectives. The first involved determining if the behaviour of the streamflow in the profiles differed between the windward (German) and leeward (Czech) sides of the mountain range. If a physicogeographical difference was found (the climatic difference being particularly noteworthy), it would be logical to assume that the occurrence and distribution of drought in these areas would also vary. The second objective was to outline the trends in hydrological drought in the mountain region, and to compare these trends with those from mid-and lower-altitude regions in Czechia. The third objective was to determine whether the trends in drought occurrence on the leeward and windward sides of the mountains differed. The working hypothesis was that there would be significant differences between the distribution and seasonality of drought occurrence on the leeward and windward sides of the mountains. Additionally, altitude might also have played a role, with more drought occurrences in winter at higher altitudes, and more at lower altitudes in summer.

An integral part of this work was to also provide an overview of the simple hydrological indices that are easy to use in the evaluation of drought, to select those indices best suited to evaluate hydrological drought in mountainous regions, and to justify and comment this selection. Interesting works on hydrological drought include those of Laaha et al. (2017), van Loon et al. (2016) and van Loon, Kumar, Mishra (2017).

\section{Simple indices of hydrological drought}

For this study, it was necessary to compile a list of easy-to-use hydrological indices for the evaluation of drought (described in the subsections below). This was important in order to enable selection of the most appropriate methods to use for data processing. Previous studies have provided such compilations, including Niemeyer 
(2008), who produced an extensive list, Novický et al. (2008) and Brázdil, Trnka et al. (2015). The performance of such drought indices have been summarised by Mishra and Singh (2010).

\subsection{Percentage of normal}

This is a simple, but rarely used, index, comprising a simple expression of the ratio of the measured runoff sums and their long-term mean values as a percentage, according to the formula:

$$
\% N=\frac{P}{\bar{P}} \times 100
$$

\subsection{Deciles method}

The principle of this method consists of dividing the cumulative probability of runoff totals for a certain period into intervals corresponding to $10 \%$ of the total distribution of the outflow (i.e. deciles). The affiliation to each decile indicates whether it was a period with a strong under-average (1-2 deciles), below average (3-4), average (5-6), above-average (7-8) or strongly above-average (9-10) outflow. This is similar to the percentage of normal method.

\subsection{Determination of drought according to Gumbel (1963)}

Gumbel's (1963) description and definition of drought fundamentally differs from the other methods described here. He defined it as the lowest daily flow in a given year. Rather than being a dryness index, this involves the analysis of annual minima. This method therefore finds one drought every year, entirely unrelated to the water present or the flow rate, etc.

\subsection{Threshold value method}

This is widely used, and is arguably the most common method (index) used, as presented by Brázdil, Trnka et al. (2015), and also mentioned by Novický et al. (2008) among other sources, including Fleig et al. (2005).

The method consists of determining the flow threshold value, where a drop in flow below this value indicates the occurrence of drought at the relevant profile. The intersection of the hydrograph with the selected limit value represents the beginning or end of a dry episode. This threshold may be constant or variable 
during a year. As a threshold value, the flow rate between $Q_{70}$ and $Q_{97.9}$ is usually selected, which corresponds to $\mathrm{Q}_{355}$.

A frequently used addition to this method is the smoothing of daily rows with the help of a sliding diameter calculation. Fleig et al. (2005) recommended that the sliding window size be 10 days.

Vorel (1937, in Novický et al. 2008) established a dry state as being an event during which the flow falls below the long-term monthly flow in the given month. Johanovský (1985, in Novický et al. 2008) used a definition in which monthly flows of less than, or equal to, $60 \%$ of the long-term flow in a given month, for three months in a row, represent a drought.

\subsection{Base flow index}

The principle of this index is that it provides the ratio of the basic (basal) outflow to the total flow. The index is counted from daily data, with the separation of the basic runoff needing to occur in a daily step (Institute of Hydrology 1992; Tallaksen, van Lanen, eds. 2004). The resulting index is used as an annual value. This is similar to how the low flow index (Poff, Ward 1989) works, which is calculated as the ratio of the lowest average daily flow per year to the average annual flow of that year. However, this index is more sensitive than others to remote values.

\subsection{World Meteorological Organization method}

World meteorological organization method, mentioned by Brázdil, Trnka et al. (2015), defines a low flow rate as being flow in the watercourse during dry weather. Brázdil, Trnka et al. (2015) added that this definition is not accurate, as low flows are not necessarily linked to such periods. According to this method, a lack of water is defined as significant if the average annual flow rate is lower than the normal flow rate by one determinant deviation, as continuous if the flow is lower than normal for four consecutive years, and as extensive if the above-mentioned situations affect the whole region.

\subsection{Index of regional streamflow deficit}

Index of regional streamflow deficit is a relatively new index. Stahl (2001) presented it (as the Regional Streamflow Deficiency Index, RSDI) as an index to define regional drought in which individual time-series of hydrological profiles represent the input data. The index is calculated in two steps. In the first, a drought is defined 
at individual stations by applying the threshold value method using the $\mathrm{Q}_{90}$ limit value. In the second step, the results from individual stations in the region are compared to each other, a regional drought being inferred when drought develops at a significant percentage of stations in the region. Technically, this is a calculation of the spatial diameter (the resulting RSDI index) of the DI index (in the sense of Vlnas, 2015). This is determined for each profile, being 1 when the flow drops below the $\mathrm{Q}_{90}$ value and 0 in all other cases. The RSDI index is thus taken to be the share of catchment areas affected by drought.

\subsection{Standardized runoff index (SRI)}

Standardized runoff index (SRI) is also widely used, and is the equivalent of the standardized precipitation index, which was first used by McKee, Doesken, Kleist (1993) as a method for determining meteorological drought. Its adaptation to a series of flows was done by Shukla, Wood (2008). The SRI is primarily used at an annual or monthly time step, and is based on the statistical transformation of data on a normalised normal distribution. First, a cumulative distribution function that can be interposed by a series of flows must be found. Subsequently, the inverse function of the normal distribution is calculated for this distribution function to give the SRI value (Kumar et al. 2006; Shukla, Wood 2008; Vlnas et al. 2014; Jianzhu, Shuhan, Rong 2016).

\subsection{Streamflow drought index (SDI)}

Streamflow drought index (SDI) is used to define drought in monthly steps, as developed by Nalbantis and Tsakiris (2009). The calculation is:

$$
\begin{gathered}
V_{i, k}=\sum_{j=1}^{3 k} Q_{i, j} \\
S D I_{i, k}=\frac{V_{i, k}-\bar{V}_{k}}{\sigma_{k}}
\end{gathered}
$$

where $V_{i, k}$ is the cumulative discharge volume for the $i$-th hydrological year and for the $k$-th reference period, $j$ denotes the relevant month, and $Q_{i, j}$ is the monthly discharge value. is the average and is the determinant deviation of the cumulative volume in $k$-th reference period. The values of $i$ are therefore $i=1,2, \ldots$, the values $j=1,2, \ldots$ and $k=1,2,3,4$. (Nalbantis, Tsakiris 2009).

Modified equations for the arbitrarily chosen time scale $k$ are given by Xingjun et al. (2015). SDI values are used to evaluate four drought probability classes. 


\section{Definition and description of the study area}

For the study of drought in a mountainous region, the Eastern European Bohemian Forest was chosen because it has hydrological profiles for which data is available. Furthermore, there is a wealth of contemporary information available as a result of the evaluations of many investigations (e.g. Vlček et al. 2012, Šachová 2013) carried out for the Charles University's Department of Physical Geography and Geoecology.

\subsection{Definition of the area}

For evaluating hydrological drought, the river basin was selected on both sides of the Bohemian Forest. This basin's closing profiles lie in the lower levels of the Bohemian Forest mountain range, sometimes even below $400 \mathrm{~m}$ above sea level. These relatively large river basins were chosen primarily to represent the entire
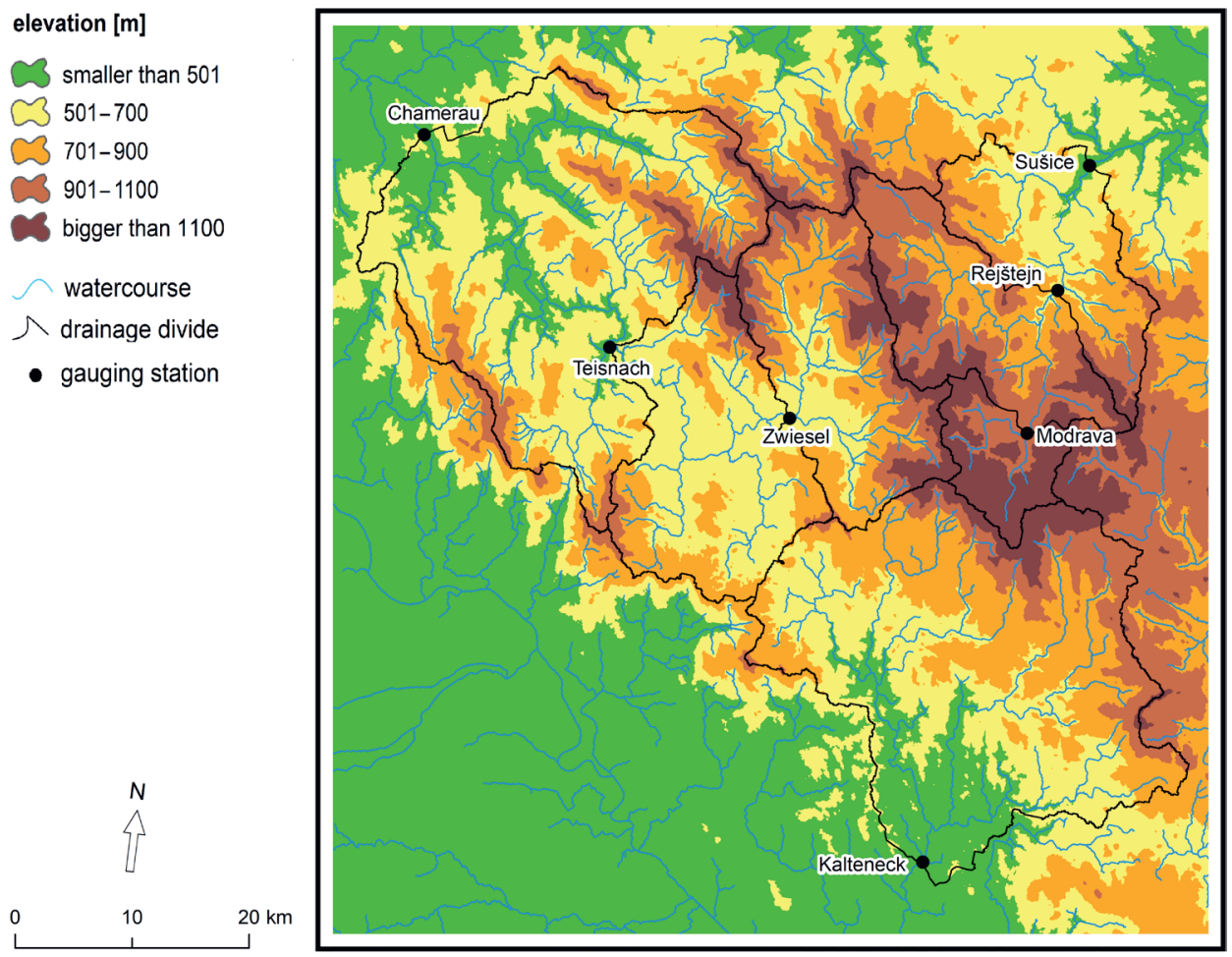

Fig. 1 - Hypsometry of the study area. Sources: EEA (2012), Jarvis et al. (2008). 
Tab. 1 - Geomorphological and hydrological characteristics of the catchment area

\begin{tabular}{lrcccccc}
\hline & $\begin{array}{c}\text { Catchment } \\
\text { area }\left(\mathrm{km}^{2}\right)\end{array}$ & $\begin{array}{c}\text { Lowest } \\
\text { altitude in } \\
\text { catchment } \\
\text { area (m a.s.l.) }\end{array}$ & $\begin{array}{c}\text { Highest } \\
\text { altitude in } \\
\text { catchment area } \\
(\mathrm{m} \text { a.s.l.) }\end{array}$ & $\begin{array}{c}\text { Average } \\
\text { altitude in } \\
\text { catchment } \\
\text { area (m a.s.l.) }\end{array}$ & $\begin{array}{c}\text { Median } \\
\text { altitude in } \\
\text { catchment area } \\
(m \text { a.s.l.) }\end{array}$ & Qa $\left(\mathrm{m}^{3} / \mathrm{s}\right)$ & $\mathrm{Q}_{355}\left(\mathrm{~m}^{3} / \mathrm{s}\right)$ \\
\hline Modrava & 90.77 & 973 & 1,376 & 1,148 & 1,140 & 3.32 & 0.82 \\
Rejštejn & 334.62 & 564 & 1,376 & 1,026 & 1,040 & 8.21 & 2.22 \\
Sušice & 537.38 & 466 & 1,376 & 922 & 936 & 10.30 & 2.80 \\
Zwiesel & 295.29 & 558 & 1,440 & 873 & 843 & 4.88 & 1.34 \\
Teisnach & 625.86 & 446 & 1,445 & 781 & 728 & 13.71 & 3.89 \\
Chamerau & 1356.76 & 371 & 1,445 & 707 & 666 & 25.67 & 7.70 \\
Kalteneck & 770.09 & 326 & 1,441 & 711 & 701 & 15.61 & 4.54 \\
\hline
\end{tabular}

Source: EEA (2012), Jarvis et al. (2008)

mountain region, and also so that it would be possible to compare the hydrological profiles of each with those from a different altitude. A map of the area of interest is shown in Figure 1. Seven hydrological profiles were selected, three on the Czech side and four on the German side. Table 1 lists some geomorphological characteristics of these profiles and their catchment areas.

\subsection{Climatic characteristics}

The climate of the region is transient, combining both oceanic and continental influences. The Bohemian Forest is windward to the prevailing southwesterly wind stream, so there are many differences between the windward and the leeward sides of the mountains. The total amount of precipitation varies, depending on altitude and exposure, from 800 to $2,500 \mathrm{~mm}$ per year, and is almost evenly distributed between the winter and summer periods in the highlands. Lower precipitation rates occur in the lower-altitude areas. The average number of days with snow cover is 120-150 days in the Bohemian Forest. Snow is an important reservoir of water, and its melting slows the rise in spring temperatures. However, there is less snow in the Bohemian Forest than in other Czech mountains, as it is under influence of the Alps (Chábera et al. 1987, Klöcking et al. 2005). The mountain range forms (from a climatic point of view) a border between the continental region of high-pressure air and the low-pressure atmospheric zones of. The drop in precipitation rates with decreasing altitude ranges from 65 to $100 \mathrm{~mm} / 100 \mathrm{~m}$, and is greater on the windward side of the mountain range (Klöcking et al. 2005). 


\subsection{Soil conditions}

In the Bohemian Forest, the soils are mainly podzols, cambisols, gleysols, lithosols and organosols, with fluvisols found in the lower-altitude river wetlands. The soil-forming substrates are predominantly acidic rocks and their weeds, with organosols found in peat solely in the foothill areas. Loamy clays can also be found at the feet of the mountain slopes (Chábera et al. 1987).

\subsection{Vegetation}

In mountainous areas, there are acidic beechwood trees, wet spruce forests and peat bogs, which are restored as potential natural vegetation, with floral beechwood predominating beneath them (Chábera et al. 1987). However, much of the natural forest vegetation has been transformed into spruce woods over the past few centuries, while large areas have been deforested. In recent decades, the Bohemian Forest has been experiencing changes in landscape coverage due to bark beetle infestations, with the impact of these changes dramatically influencing hydrological patterns, as well as climate change, as noted by Bernsteinová et al. (2015).

Peat bogs are particularly important, hydrologically, but due to their small areal proportion of the catchment areas, their influence has not been specifically studied. The hydrogeology of organosols has been discussed in detail by Vlček et al. $(2012,2016)$, for example.

\section{Data sources and methodology}

\subsection{Data sources}

For the hydrological profiles on the Czech side, data from the Czech Hydrometeorological Institute (ČHMÚ) were used. This data covered the hydrological years 1931 to 2014 (at which point the data was no longer available), although the data from the late 1930s and most of the 1940s from Rejštejn and Modrava are missing. This data was kindly provided by Bohumír Janský and Zdeněk Kliment.

Data from the German profiles was obtained from a freely available source on the Bavarian Hydrological Service website of the Bavarian Federal Environmental Office (GKD) (http://www.gkd.bayern.de/index.php?sp=en). This data was visually inspected, and no anomalies were found.

As a period for which the analyses were performed, a period for which data from all the hydrological profiles studied was available. The monitored period thus covers the hydrological years 1931-1937 and 1949-2014. 


\subsection{Methods used}

The methods used were divided into two categories - hydrological calculations and statistical tests. From the indices, those chosen were: (1) usable for daily data series; (2) provided clear information about the extremity of the drought, and always distinguished the same proportion of dry days at each profile: and (3) allowed each hydrological profile to be evaluated separately.

On the basis of the aforementioned criteria, the threshold and Gumbel (1963) methods, and the calculation of scarcity volumes, were selected for time-series data evaluation. The threshold method differs significantly from the Gumbel (1963) method, making it possible to compare the two. It was of particular interest to be able to compare the seasonality of the dry days between them. The $\mathrm{Q}_{355}, \mathrm{Q}_{97.19}$. By means of these methods, the dry days were determined at the hydrological profiles, and charts of the seasonality of the dry days were able to be constructed.

To test for the presence of a hydrological drought trend, the Mann-Kendall and Hirsch-Slack tests, and the Mann-Kendall test modified by the Zhang method and Sen's guideline estimation method, were used. This is a nonparametric test that does not assume the normality of the data and is not sensitive to outlying values and low-grade, nonlinear trends. The test is used to identify the monotone trend in a time-series. The zero hypothesis of this test is that the data observed is independent and has the same distribution. An alternative hypothesis is the presence of a monotone trend in the time-series data. The Mann-Kendall test's test statistic was calculated by (Vlnas 2015):

$$
S=\sum_{i=1}^{n-1} \sum_{j=i+1}^{n} \operatorname{sgn}\left(X_{j}-X_{i}\right)
$$

where $\operatorname{sgn}(\Theta)=1$ when $\Theta>0$, = 0 when $\Theta=0$, and $=-1$ when $\Theta<0$.

The Mann-Kendall test, in its basic form, was used to test time-series containing monthly sums of days marked as dry by the threshold method. This gave an overall trend for the time-series.

In addition, the same time-series were analysed by dividing them into individual months. The trends in the occurrence of dry days in the individual months (i.e. changes in seasonality) were tested. For the purpose of this test, the Hirsch-Slack test (a seasonal variant of the Mann-Kendall test) was used. The test statistic was calculated analogously. Describing and applying this test to water-quality data has been dealt with by Hirsch, Slack and Smith (1982).

To test the trend in the time-series of deficit volumes, a modified approach was used for technical reasons. These time-series were evaluated as the original, daily data because the conversion of time-series of deficit volumes into monthly or annual steps is a problematic issue that has not yet been resolved. Mann-Kendall's 
trend test modified by the Zhang method was used (Wang, Swail 2001). The calculation procedure consisted of not calculating the test statistic in the first step; the test first calculates the nonlinear trend by the Zhang method, followed by the Mann-Kendall trend-trend test.

\section{Results}

\subsection{Evaluation of time-series by means of statistical tests}

Table 2 shows the result of the trend evaluation for the daily time-series of scarce volumes.

In Table 2, the key value is the significance level, since this determines the degree to which a monotonous ascending or descending trend is present. The guideline here was calculated very simply as a linear trend guideline determined by the least squares method from the original data. Tau is the Mann-Kendall coefficient of sequence correlation, thus expressing the presence of the trend. Analysis of Table 2 confirms that almost all the profiles presented a decreasing trend in the time-series of deficit volumes. This downward trend (negative directive) occurred everywhere, but in one case, in the Chamerau profile, it was not confirmed as significant. For all the other profiles, significance at the $5 \%$ confidence level was achieved, except for Zwiesl, which was at $1 \%$. These results generally confirm a gradual decline in the time-series, sometimes leading to the disappearance of dry episodes, which contradicts the theory of the arrival of summer droughts in the Central European region with advancing climate change.

In the next survey, monthly sums of days marked as dry by the threshold method were used in the statistical testing of drought trends. These time-series were used as data for the Mann-Kendall trend test in its basic form. The main test results are the test statistics $S$, the Mann-Kendall coefficient of tau sequence correlation, and the $\mathrm{p}$-value expressing the trend significance. The results contradicted the previous testing, in that the Chamerau profile was evaluated similarly to the others, and therefore the presence of a monotonous decreasing trend of hydrologic

Tab. 2 - Results of the Mann-Kendall's trend test for the time-series of scarce volumes

\begin{tabular}{lllllllc}
\hline & Modrava & Rejštejn & Sušice & Zwiesel & Teisnach & Chamerau & Kalteneck \\
\hline tau & -0.035 & -0.02159 & -0.02182 & -0.0117 & -0.02227 & -0.00241 & -0.01964 \\
sig. & 0.00000 & 0.000003 & 0.000002 & 0.011259 & 0.000001 & 0.598408 & 0.000021 \\
guideline & -0.000027 & -0.00004 & -0.000036 & -0.000001 & -0.00002 & -0.000001 & -0.000019 \\
\hline
\end{tabular}

Sources: ČHMÚ 2018, GKD 2017 
Tab. 3 - Results of the Mann-Kendall's trend test in the time-series of the monthly number of dry days

\begin{tabular}{lccccccc}
\hline & Modrava & Rejštejn & Sušice & Zwiesel & Teisnach & Chamerau & Kalteneck \\
\hline tau & -0.21 & -0.15 & -0.11 & -0.10 & -0.12 & -0.32 & -0.12 \\
S & $-30,966$ & $-22,279$ & $-16,498$ & $-16,414$ & $-19,242$ & $-62,690$ & $-20,496$ \\
sig. & 0.00000 & 0.00000 & 0.000048 & 0.000207 & 0.000006 & 0.000000 & 0.000006 \\
\hline
\end{tabular}

Sources: ČHMÚ 2018, GKD 2017

drought was confirmed. The p-values were extremely low for all the profiles, so the zero hypotheses were rejected with strong confidence. Test statistic $S$ was shown, paradoxically, in the Chamerau profile to be the lowest in all the profiles, along with Mann-Kendall's tau, so it was deduced that the presence of a decreasing trend in the number of dry days was the strongest contradiction to the previous test. The profiles appear to be quite similar in terms of these trends, and although there are differences in the test statistics, they all share the inclination that the presence of the trend was confirmed at the $1 \%$ confidence level (Table 3 ).

Tests for seasonality changes and, more precisely, trend tests for drought occurrence are presented separately for the individual months in Table 4. In terms of the time-series, the same data used in the previous case (i.e. monthly sums of dry days based on the threshold method) were used. The test was the same as the previous one - the basic variant of the Mann-Kendall trend test. However, a seasonal modification - also known as the Hirsch-Slack test - was used. Calculation of the test statistics (S) was zero (the same as found from previous testing), and the alternative hypotheses were also identical.

These results are very similar to those from the previous trend-testing that did not divide them into individual months, although those in Table 4, by testing the trend for each month for each profile, give a far more plastic picture of the situation at individual profiles. At most of the profiles, there were months when no drought was observed throughout the monitored period, or only a negligible number of values were present and so the test could not be calculated. In the vast majority of cases, a decreasing trend of dry days was detected, whilst in only in three profiles were there months in which the number of dry days increased Kalteneck (June), Teisnach (June) and Sušice (August). All of these upward trends, however, were very insignificant and should not be regarded as relevant results or as defining a clearly confirmed trend.

Unlike the previous test, which explored the entire time-series without splitting the data into individual months, there were significant differences between the different profiles. The situation in comparing the individual profiles and the months with the decreasing trend is very different. The Zwiesel profile was the only one where the monthly data failed to show any trend, although some months with 
p-values of 0.05 were quite close. This was the one most similar to the Teisnach profile, where only a declining trend in dry days in January and November was marked as significant, and at only a $5 \%$ confidence level. It is noteworthy that, in the case of the seasonal distribution of dry days, according to the threshold and

Tab. 4 - Results of the Mann-Kendall trend test for the time-series of the monthly number of dry days, by individual month

\begin{tabular}{|c|c|c|c|c|c|c|c|c|}
\hline & Month & Modrava & Rejštejn & Sušice & Zwiesel & Teisnach & Chamerau & Kalteneck \\
\hline \multirow[t]{12}{*}{ Tau } & January & -0.23 & -0.28 & -0.25 & -0.15 & -0.24 & -0.35 & -0.12 \\
\hline & February & -0.21 & -0.12 & -0.13 & -0.15 & -0.18 & -0.32 & $\mathrm{NaN}$ \\
\hline & March & -0.10 & -0.12 & -0.17 & -0.10 & -0.09 & -0.29 & $\mathrm{NaN}$ \\
\hline & April & -0.16 & $\mathrm{NaN}$ & $\mathrm{NaN}$ & $\mathrm{NaN}$ & $\mathrm{NaN}$ & -0.25 & -0.17 \\
\hline & May & $\mathrm{NaN}$ & $\mathrm{NaN}$ & $\mathrm{NaN}$ & $\mathrm{NaN}$ & $\mathrm{NaN}$ & -0.32 & -0.21 \\
\hline & June & $\mathrm{NaN}$ & $\mathrm{NaN}$ & $\mathrm{NaN}$ & -0.08 & 0.02 & -0.36 & 0.03 \\
\hline & July & -0.18 & $\mathrm{NaN}$ & -0.04 & -0.11 & -0.11 & -0.37 & -0.13 \\
\hline & August & -0.19 & -0.13 & 0.02 & -0.07 & -0.11 & -0.35 & -0.17 \\
\hline & September & -0.29 & -0.04 & -0.05 & -0.11 & -0.04 & -0.32 & -0.22 \\
\hline & October & -0.32 & -0.23 & -0.12 & -0.17 & -0.16 & -0.38 & -0.14 \\
\hline & November & -0.29 & -0.27 & -0.19 & -0.16 & -0.23 & -0.38 & -0.20 \\
\hline & December & -0.34 & -0.22 & -0.19 & -0.03 & -0.16 & -0.30 & -0.19 \\
\hline \multirow[t]{12}{*}{$\mathrm{S}$} & January & -331 & -458 & -379 & -192 & -360 & -473 & -85 \\
\hline & February & -264 & -145 & -171 & -166 & -193 & -419 & $\mathrm{NaN}$ \\
\hline & March & -114 & -124 & -164 & -84 & -78 & -318 & $\mathrm{NaN}$ \\
\hline & April & -120 & $\mathrm{NaN}$ & $\mathrm{NaN}$ & $\mathrm{NaN}$ & $\mathrm{NaN}$ & -185 & -103 \\
\hline & May & $\mathrm{NaN}$ & $\mathrm{NaN}$ & $\mathrm{NaN}$ & $\mathrm{NaN}$ & $\mathrm{NaN}$ & -332 & -254 \\
\hline & June & $\mathrm{NaN}$ & $\mathrm{NaN}$ & $\mathrm{NaN}$ & -46 & 11 & -426 & 45 \\
\hline & July & -109 & $\mathrm{NaN}$ & -23 & -90 & -82 & -499 & -206 \\
\hline & August & -142 & -141 & 17 & -90 & -137 & -543 & -273 \\
\hline & Septemberr & -317 & -43 & -58 & -156 & -51 & -463 & -336 \\
\hline & October & -396 & -291 & -138 & -276 & -185 & -587 & -163 \\
\hline & November & -343 & -356 & -199 & -234 & -331 & -588 & -191 \\
\hline & December & -419 & -325 & -269 & -45 & -211 & -445 & -136 \\
\hline \multirow[t]{12}{*}{ Sig. } & January & 0.013 & 0.003 & 0.008 & 0.121 & 0.011 & 0.000 & 0.237 \\
\hline & February & 0.026 & 0.198 & 0.168 & 0.118 & 0.069 & 0.001 & $\mathrm{NaN}$ \\
\hline & March & 0.284 & 0.211 & 0.071 & 0.308 & 0.344 & 0.003 & $\mathrm{NaN}$ \\
\hline & April & 0.094 & $\mathrm{NaN}$ & $\mathrm{NaN}$ & $\mathrm{NaN}$ & $\mathrm{NaN}$ & 0.010 & 0.081 \\
\hline & May & $\mathrm{NaN}$ & $\mathrm{NaN}$ & $\mathrm{NaN}$ & $\mathrm{NaN}$ & $\mathrm{NaN}$ & 0.001 & 0.032 \\
\hline & June & $\mathrm{NaN}$ & $\mathrm{NaN}$ & $\mathrm{NaN}$ & 0.441 & 0.864 & 0.000 & 0.768 \\
\hline & July & 0.064 & $\mathrm{NaN}$ & 0.706 & 0.274 & 0.254 & 0.000 & 0.170 \\
\hline & August & 0.047 & 0.184 & 0.879 & 0.450 & 0.248 & 0.000 & 0.068 \\
\hline & September & 0.003 & 0.669 & 0.611 & 0.244 & 0.671 & 0.001 & 0.018 \\
\hline & October & 0.001 & 0.014 & 0.221 & 0.065 & 0.100 & 0.000 & 0.148 \\
\hline & November & 0.002 & 0.004 & 0.044 & 0.090 & 0.013 & 0.000 & 0.036 \\
\hline & December & 0.000 & 0.019 & 0.044 & 0.721 & 0.102 & 0.001 & 0.057 \\
\hline
\end{tabular}

$\mathrm{NaN}$ - no data

Sources: ČHMÚ 2018, GKD 2017 
annual minima method, the Teisnach profile was judged to be very specific, and there was no significant difference between this and the other profiles in assessing trends in these values. A weak trend was also found in the Kalteneck profile, although only three months (May, September and November) showed a declining trend in dry days.

The Chamerau station was fundamentally different from all the other German profiles. Where a decreasing trend in droughts in all months was confirmed, it was always at a $1 \%$ confidence level. It is paradoxical that, in this case, as in the case of the trends tested in the time-series of scarce volumes, this profile differed completely from the others, but here in the opposite way, with a descending trend of dry days, according to the threshold method, being extremely significant in each individual month.

The Czech profiles were quite similar to each other. Typically, a decreasing trend in the occurrence of dry days was found in some autumn or winter months. The effect of different altitudes is obvious. At the highest elevation, in Modrava, there were significant decreasing drought trends from August to February, while at the lowest elevation (Sušice), the trend concerned only the months of November, December and January.

The rate of trend significance declined with decreasing altitude. However, altitude affected only the Czech profiles, with the German profiles being unclear in this respect. In addition to the influence of altitude on the Czech side, there were no clear differences, similarities or influences that would have prompted us to divide the profiles into groups or describe the characteristics of their differences in more detail. In the case of the trends, the Czech profiles were not markedly different from the German ones.

\subsection{Assessment of drought seasonality}

Below are the results of the seasonal drought evaluation on the individual profiles, according to the two selected hydrological drought indexes - the threshold method with a threshold of $\mathrm{Q}_{355}\left(\mathrm{Q}_{97.19}\right)$ and the Gumbel (1963) method.

Figure 2 shows the seasonality of individual dry-day profiles using the threshold method at the $\mathrm{Q}_{355}$ limit $\left(\mathrm{Q}_{97.19}\right)$. The relative similarity of most of the German profiles with other and the Czech ones with each other is striking. Figure 2 also shows that, although there are some differences between individual German and individual Czech profiles, their differences are generally marginal compared to the fundamental difference between the Czech and German sides of the Bohemian Forest, and therefore between the 'average' Czech and German profile. The difference between most of the German profiles and the Czech ones is that, on the Czech side, the dry days are mostly concentrated in the winter (December to March) 


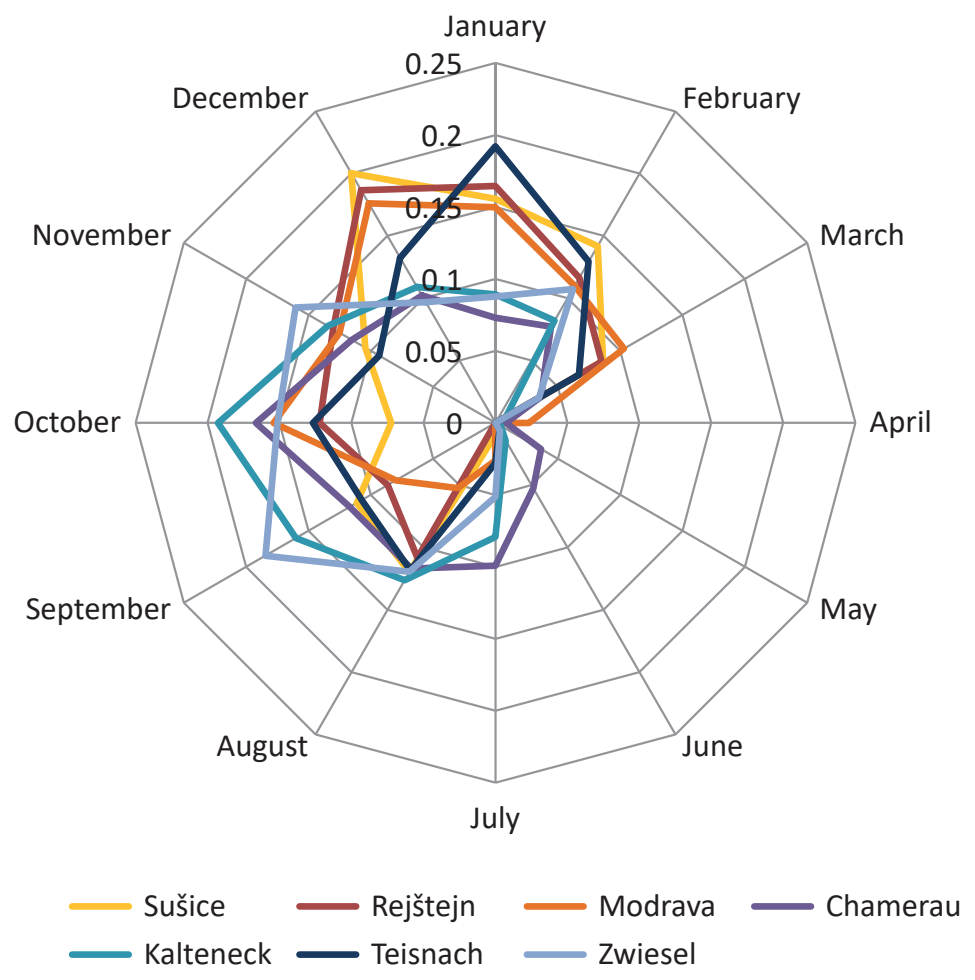

Fig. 2 - Dry-day seasonal distribution by the threshold value method. Sources: ČHMÚ 2018, GK. 2017.

months, whereas on the German side, they reach maximum values in the autumn months, especially in October.

The Czech profiles can be said to be mutually more similar than the German ones. The drought rate in August and September decreased with the increasing altitude of the profile, while the significance of droughts in October increased along with increasing altitude. The German profiles were mutually less similar. Apart from the Teisnach profile, however, common features can be observed, especially in the prevalence of drought occurrence in the autumn months. As to the number of dry days, February (among the winter months) fell behind in comparison to the Czech profiles, but the difference here was quite obvious. The majority of German profiles were characterised by a slightly lower concentration of dry days in their driest months, although this was not a significant difference. The share of October droughts in the German profiles increased with decreasing profile altitude, as well as with the proportion of dry days in the summer months. The proportion of February dry days, on the other hand, decreased with decreasing altitude. All profiles (both Czech and German) coincided in having virtually no droughts in 


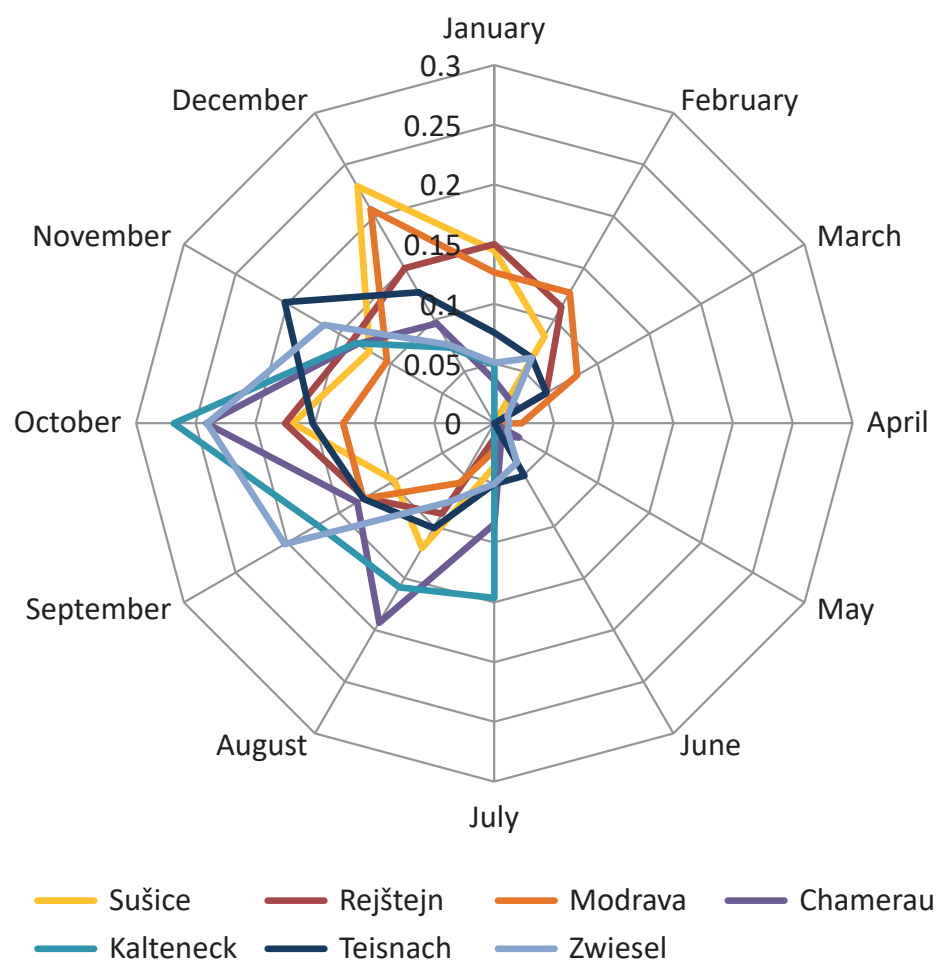

Fig. 3 - Annual minima seasonal distribution. Sources: ČHMÚ 2018, GKD 2017.

April and May. A separate case was the Teisnach profile. As Figure 2 shows, the seasonality of its dry days differed completely from those of all the others, but in other respects, it was similar to the other German profiles. However, it was most similar to the Czech profiles, particularly that of Rejštejn.

It can be seen that there are two well-defined groups of stations that deviate from the specific situation in the Teisnach profile, which differ fundamentally from drought seasonality, thus confirming the hypothesis concerning the significance of the leeway and wind effect on the mechanisms of hydrological drought. Altitude has an obvious influence on the seasonality on the Czech and German sides, although its effect is manifested markedly differently on each side.

Figure 3 deals with seasonality, and represents an analogue of the Figure 2, but contains the seasonal data of dry days according to the Gumbel (1963) method (i.e. the de facto yearly minima). Here, similar patterns to those in Figure 2 can be seen; namely, that the German and Czech profiles are divided into two groups that are internally homogeneous and mutually different. While on the Czech side, the dry days are concentrated in the winter period, on the German side, they 
are predominantly in the autumn. The most striking difference for the Czech profiles is the absence of a very significant maximum of dry days in the profile of Rejštejn, which, with its October maxima, is more similar to the German profiles. No German profile has a similar pattern to any other of the Czech ones.

Differences between the German profiles are mainly based on the difference in the annual minimum in summer, which generally increased with decreasing altitude. However, in the case of the annual minima, the effect of different altitude was far less observable than in the case of dry-day seasonality by the threshold value method. Interestingly, while in the previous case, the number of dry days in the driest month in the Czech profiles was more concentrated, in the case of the annual minima, the situation is different because the German profiles appear to be more 'concentrated'. It is also worth studying the profile of Teisnach. In the case of dry days measured by the threshold value method, the Czech profile appeared to be typical, but this is not the case for the other method. In the distribution of annual minima, Teisnach is close to the other German profiles, which are essentially identical in terms of the shape of the seasonality curve, but it has a maximum shifted from October to November, and this maximum is considerably lower than that of the other German profiles. It is also characterised by a higher proportion of winter drought and a lower summer drought share, which corresponds to the displaced maximum and to the distribution of months less rich in drought around it.

\section{Discussion}

This evaluation of selected hydrological profiles has produced a number of answers to the questions posed at the beginning of this work. Nevertheless, it is obvious that, with limited data sources and a small number of methods that could be used, it is not possible to fully describe the situation of hydrological drought in the Bohemian Forest region.

The most significant result is that the seasonality of drought differs significantly between the Czech leeward side and the German windward side of the Bohemian Forest mountains, although this distribution is slightly disrupted by the specific example of the Teisnach profile. Trend tests of the deficit volumes and of the number of dry days at each profile gave a further insight into the situation at the profiles, and revealed other similarities and differences. First of all, the Teisnach profile does not differ fundamentally from the other profiles, in terms of the observable trends. On the other hand, Chamerau otherwise appears to be a 'normal' profile. There was no significant difference between the trends in the Czech and German profiles, either generally or monthly, but there was a rather distinct difference between the profiles at different altitudes (but only in the Czech profiles), although this was rather difficult to observe in the case of seasonal 
drought distribution. Moreover, the methodical result is that very similar tests performed quite differently on the Chamerau profile on time-series containing similar data, which suggests that it is appropriate to use multiple approaches to verify whether or not the results are accurate and consistent. A list of frequently used, simple hydrological indices was created so that methods could be identified that would be suitable for evaluating hydrological time-series data.

Šachová (2013) was partly concerned with an evaluation of the Modrava, Rejštejn and Sušice profiles, concluding that Modrava was dominated by winter drought, while summer droughts were prevalent in Sušice. The results presented herein contradict this finding, with the maximum hydrological drought at Sušice being found in the winter. This difference can be accounted for primarily by the selection of divergent thresholds, but perhaps also because Šachová (2013) used a different time period for the evaluation; she found severe summer drought in 1947.

Similar results were reported by Kliment and Matoušková (2008). They evaluated the change in monthly flows in the Vydra, Blanice and Ostružná rivers, using the Mann-Kendall test. They found an increase in outflow in February and March in the Blanice river, and a decrease from April to June, an outflow decrease in the Ostružná river in the autumn months and a decrease in July, and an increase in April in the Vydra river (in Modrava). This does not correspond neatly with the dry-day trends in the Modrava profile herein. However, it is necessary to take into account the different periods under review (here 1962-2002; Kliment and Matoušková, 2008).

Brázdil, Trnka et al. (2015) reported interesting data on an agricultural drought assessment in Czechia. Trends in the maximum annual deficiency volumes at the Q95 threshold were evaluated as increasing in most of Czechia, whilst decreasing in mountain and foothill areas, which corresponds well with the results of the statistical tests outlined in this paper. There was also a seasonal distribution of dry days in the Pilař profile (Lužnice river), according to the threshold method using $\mathrm{Q}_{355}$ (Svoboda 2011, in Brázdil, Trnka et al. 2015). From this, it is obvious that the seasonality of dry days they found differs from the Bohemian Forest profiles. In the Pilař profile, the dry days are concentrated in July, August and September, with only a few less in November. It is also worthwhile mentioning the different behaviour of mid-altitude catchment areas in relation to the mountain region. Unfortunately, seasonality at the Pilař profile was evaluated only in 1965-2010, so this comparison should be made with care.

Vlnas (2015) dealt with, among other things, the definition of linear trends in the series of monthly and annual aggregations of seven-day moving daily measured minimum flows for 161 stations in Czechia. He showed that the annual minimum flow rates are declining, which does not correspond to the trends listed here. In addition, Vlnas et al. (2010) listed trends in deficit volumes for the period 1947-2007. This period roughly corresponds to the period used in this work, thus 
adding validity to this comparison. In this period, Vlnas et al. (2010) only found decreasing trends in scarcity volumes in Czechia. This correlates well with the results of the test used for the Bohemian Forest profiles.

\section{Conclusions}

This work dealt with the evaluation of hydrological drought in an area where it is not that common, given the fact that mountainous areas in Central European regions do not usually suffer from drought. The findings lead to the conclusion that there are significant differences between the occurrence of drought on the windward and leeward sides of the mountain range, the differences being observable even in hydrological drought occurrence trends. However, the spatial distribution of trends remains obscure. Despite the ambiguity, this information invites intriguing new questions. Apart from the possibility of further study of the region, by means of a larger number of shorter time-series, the most interesting question appears to be whether these differences are manifested in the other (border) mountains of Czechia. The answer to this question is not only relevant from the research aspect, but also from a water management point of view because these mountains are often adjacent to densely populated areas with limited drinking water resources. Water resources in these mountain ranges are likely to be used more intensively in the future.

\section{References}

BERNSTEINOVÁ, J., BÄSSLER, C., ZIMMERMANN, L., LANGHAMMER, J., BEUDERT, B. (2015): Changes in runoff in two neighbouring catchmenst in the Bohemian Forest related to climate and land cover changes. Journal of Hydrology and Hydromechanics, 63, 4, 342-352.

BRÁZDIL, R., TRNKA, M. et al. (2015): Sucho v českých zemích: minulost, současnost, budoucnost. Centrum výzkumu globální změny Akademie věd České republiky, v. v. i., Brno.

CHÁBERA, S. et al. (1987): Příroda na Šumavě. Jihočeské nakladatelství, České Budějovice.

FLEIG, A.K., TALLAKSEN, L.M., HISDAL, H., DEMUTH, S. (2005): A global evaluation of streamflow drought characteristics. Hydrology and Earth System Sciences, 10, 4, 535-552.

GUMBEL, E.J. (1963): Statistical forecast of drought. Bulletin of the International Association of Scientific Hydrology, 8, 1, 5-23.

HIRSCH, R., SLACK, J., SMITH, R. (1982): Techniques of trend analysis for monthly water quality data. Water Resources Research, 18, 1, 107-121.

Institute Of Hydrology (1992): Low flow estimation in the United Kingdom. Institute of Hydrology, Wallingford.

JIANZHU, L., SHUHAN, Z., RONG, H. (2016): Hydrological drought class transtition using SPI and SRI time series by longlinear regression. Water Resource Management, 30, 2, 669-684. 
KLIMENT, Z., MATOUŠKOVÁ, M. (2008): Runoff Changes in the Bohemian Forest Mountains and the Foothill Regions: Extent of Influence by Human Impact and Climate Change. Water Resources Management, 23, 9, 1813-1834.

KLÖCKING, B. et al. (2005): Auswirkungen des Borkenkäferbefalls auf den Wasser und Stoffhaushalt zweier Gewässereinzugsgebiete im Nationalpark Bayerischer Wald. Schriftenreihe Wasserhaushalt und Stoffbilanzen im naturnahmen Einzugsgebiet Grosse Ohe. Nationalparkverwaltung Bayerischer Wald, Grafenau.

KUMAR, N.M., MURTHY, C.S., SESHA, M., ROY, P.S. (2006): On the use of Standardized Precipitation Index (SPI) for drought intensity assessment. Meteorological Applications, 16, 3, 381-389.

LAAHA, G. et al. (2017): The European 2015 drought from a hydrological perspective. Hydrology and earth systems sciences, 21, 6, 3001-3024.

MCKEE, T.B., DOESKEN, N., KLEIST, N.J. (1993): The relationship of drought frequency and duration to time scales, http://www.droughtmanagement.info/literature/AMS_Relationship_ Drought_Frequency_DDuratio_Time_Scales_1993.pdf (10.8.2017).

MISHRA, A.K., SINGH, V.P. (2010): A review of drought concepts. Journal of hydrology, 391, 1-2, 202-216.

NALBANTIS, I., TSAKIRIS, G. (2009): Assesment of hydrological drought revisited. Water Resources Manegment, 23, 5, 881-897.

NIEMEYER, S. (2008): New drought indexes. In: Lopéz-Francos, A. (ed.): Drought Manegment: Scientifit and Technological Innovations. CIHEAM, Zaragoza, 267-274.

NOVICKÝ, O. et al. (2008): Časová a plošná variabilita hydrologického sucha v podmínkách klimatické změny na území České republiky. Zpráva za rok 2008. VúV T. G. M., Praha.

POFF, N., WARD, J. (1989): Implication of streamflow variability and predictability for Lotic community structure: a regional analysis of streamflow patterns. Canadian Journal of Fisheries and Aquatic Science, 46, 10, 1805-1818.

SHUKLA, S., WOOD, A.W. (2008): Use of standardized runoff index for characterising hydrological drought. Geophysical Resarch Letters, 35, 2, 1-7.

STAHL, K. (2001): Hydrological drought - a Study Across Europe. Disertation Thesis. AlbertLudwig Universität, Freiburg.

ŠACHOVÁ, B. (2013): Vliv klimatické změny na hydrologické sucho v povodí horní Otavy. Diplomová práce. PřF UK, Praha.

TALLAKSEN, L.M., VAN LANEN, H.A., eds. (2004): Hydrological drought: Processes and estimation methods for streamflow and groundwater. Developments in water science. Elsevier Science B. V., Amsterdam.

VAN LOON, A. et al. (2016): Drought in anthropocene. Nature geoscience, 9, 2, 89-91.

VAN LOON, A., KUMAR, R., MISHRA, V. (2017): Testing the use of standardised indices and GRACE satellite data to estimate the European 2015 groundwater drought in near-real time. Hydrology and earth system sciences, 21, 4, 1947-1971.

VLČEK, L. et al. (2012): Retenční potenciál a hydrologická bilance horského vrchoviště: případová studie Rokytecke slatě, povodí horní Otavy, jz. Česko. Geografie, 117, 4, 395-414.

VLČEK, L. et al. (2016): Influence of peat soils on runoff process: case study of Vydra River headwaters, Czechia. Geografie, 121, 2. 235-253.

VLNAS, R. et al. (2010): Časová a plošná variabilita hydrologického sucha v podmínkách klimatické změny na území České republiky. Výzkumný ústav vodohospodářský T. G. Masaryka, v. v. i., Praha. 
VLNAS, R. et al. (2014): Metodika pro stanovení mezních indikátorů hydrologického sucha. Závěrečná zpráva projektu Návrh koncepce řešení krizové situace vyvolané výskytem sucha a nedostatkem vody na území ČR. Výzkumný ústav vodohospodářský T. G. Masaryka, v. v. i., Česká zemědělská univerzita v Praze, Praha.

VLNAS, R. (2015): Pozorované změny složek hydrologické bilance z hlediska využitelných vodních zdrojů. Vodní hospodářství - Vodohospodářské technicko-ekonomické informace, $57,4-5,27-32$.

WANG, X.L., SWAIL, V.R. (2001): Changes in extreme wave heights in northern hemisphere oceans and related atmospheric circulation regimes. Journal of Climate, 14, 10, 2204-2221.

XINGJUN, H., SHENGLIAN, G., YANLAI, Z. LIHUA, X. (2015): Uncertainties in assessing hydrological drought using streamflow drought index for the upper Yangtze River basin. Stochastic Environmental Resarch and Risk Assessment, 29, 4, 1235-1247.

\section{Data and digital sources}

ČHMÚ (2018): Database of hydrological profiles on the Czech side for hydrological years 1931 to 2014. ČHMÚ, Prague.

EEA (2012): European catchments and Rivers network system (Ecrins). European Environmental Agency, https://www.eea.europa.eu/data-and-maps/data/european-catchments-and-riversnetwork\#tab-figures-produced (10.8.2017).

GKD (2017): Gewässerkundlicher Dienst Bayern, Bayerisches Landesamt für Umwelt, http:// www.gkd.bayern.de/index.php (30.4.2017).

JARVIS, A., REUTER, H.I., NELSON A., GUEVARA E. (2008): Hole-filled SRTM for the globe Version 4, CGIAR-CSI SRTM 90m Database, http://srtm.csi.cgiar.org/ (10.8.2017).

R Core Team (2014): R: A language and environment for statistical computing. R Foundation for Statistical Computing, http://www.R-project.org/ (10.8.2017).

\section{ACKNOWLEDGMENTS}

The research was funded by the Czech Science Foundation project (GA ČR), project No. 19-05011S (Spatial and temporal dynamics of hydrometeorological extremes in montane areas) and by TA ČR, project No. SS02030040 (Prediction, Evaluation and Research for Understanding National sensitivity and impacts of drought and climate change for Czechia).

The authors are indebted to Ing. Radek Vlnas for valuable methodological comments and insights.

\section{ORCID}

VÍT SKÁLA

https://orcid.org/ 0000-0002-8556-5021

BOHUMÍR JANSKÝ

https://orcid.org/ 0000-0002-2547-307X 